\title{
Bibelkurs for 5. trinn
}

\author{
Av Anny Holien, \\ kateket og leder for trosopplaring i Østre Toten kirkelige Fellesråd. E-post: ah538@kirken.no
}

- Hvordan kan vi begrunne skole-kirkesamarbeid ut ifra den nye lareplanen for grunnskolen?

- Kan vi fortsette med bibelkurs på 5. trinn? Hva slags opplegg kan vi tilby? Hva er en velegnet alder for bibelkurs?

I mine 30 år som kateket $i$ ulike menigheter har skole-kirkesamarbeid vart en meningsfull og inspirerende del av arbeidet. Jeg har sarlig gledet meg over motet med elevene på mellomtrinnet, og på 5. trinn spesielt, der jeg har hatt bibelkurs. I denne artikkelen vil jeg presentere mitt undervisningsopplegg for et slikt kurs.

\section{FORANKRING I NY LÆREPLAN}

I løpet av 2020 innføres nye læreplaner i grunnskolen. Den nye planen er langt åpnere og har færre kompetansemål enn den gamle. I tidligere plan var det listet opp en rekke konkrete mål for hva elevene skulle lære for eksempel om Bibelens oppbygning, språk, kultur og innhold. Den nye læreplanen nevner ikke Bibelen, eller noen andre hellige skrifter som sådan. Likefullt kan skole-kirkesamarbeid etter mitt syn fortsatt begrunnes i skolens planer.

I overordnet del av skolens læreplanverk kan skole-kirkesamarbeid knyttes til punkt 1.1. Menneskeverdet, med stikkordene likeverd, tilgivelse, nestekjærlighet og solidaritet.

I punkt 1.2. Identitet og kulturelt mangfold står det «Innsikt i historie og kultur er viktig for utvikling av elevenes identitet ... elevene skal lære å kjenne de verdiene og tradisjonene som bidrar til å samle menneskene i landet. Kristen og humanistisk arv har spilt en sentral rolle ...» (Utdanningsdirektoratet 2017).

Bibelkurset kan også knyttes til kompetansemål i den nye KRLE-planen, selv om Bibelen ikke er nevnt der. Følgende kompetansemål etter 7. årstrinn er aktuelle:

- "Gjøre rede for historien til kristendom og andre religioner og livssyn i Norge, inkludert samers og nasjonale minoriteters religions- og livssynshistorie

- Beskrive og presentere noen sentrale rituelle praksiser og etiske normer i kristendom

- Utforske og sammenligne tekster og materielle uttrykk som kilder til kunnskap om kulturarv knyttet til kristendom og ulike religions- og livssynstradisjoner.» (Utdanningsdirektoratet 2019)

Prismet - IKO-Forlaget 2020

Tilgjengelig på https://journals.uio.no/index.php/prismet Publisert under CC BY-NC 4.0.

Årgang 71, hefte 2, s. 195-203

ISSN: 0032-8847, ISSN online:2535-311x 


\section{BIBELKURS FOR 5. TRINN}

Hver høst sender jeg brev til skolene med tilbud om bibelkurs for 5. trinn, og ber dem ta kontakt og avtale dag og tid. Opplegget varer ca.60 minutter, og økta er delt $i$ to bolker.

Målet for Bibelkurset er at elevene skal:

- Bli kjent med Bibelen som primær artefakt

- Lære om historien til kristendommen gjennom å bli kjent med Bibelen, dens tilblivelse, språk og innhold

- Oppleve mestring i å finne fram i Bibelen

- Bli kjent med bibelske personer og sentrale hendelser knyttet til jødedom og kristendom

Utdeling av Bibel eller Nytestamente og tilbud om opplæring om Bibelen har lange tradisjoner mange steder $\mathrm{i}$ landet vårt. Det kan likevel være grunn til å spørre, hvorfor gjør vi det, og hvorfor på mellomtrinnet? Er det fordi vi alltid har gjort det? Nei, det er også gode pedagogiske grunner. Min erfaring er at $\mathrm{i}$ 10-13-årsalderen er barna nysgjerrige, faktaorientert og liker å lære nye ting. De trives med å utforske, undersøke og løse oppgaver av ulike slag. Dette fremheves også i rapporten om barn og unges respons på bibelundervisning i Den norske kirke, der Heid Leganger-Krogstad skriver: «Særlig systemlæring er morsomt i denne alderen, slik som å lære Bibelens oppbygning og det å finne fram i Bibelen» (Leganger-Krogstad 2019:147).

Elevene trenger å ha Bibler tilgjengelig på kurset. Da vi av ulike grunner sluttet å dele ut Bibler til alle elevene på 5. trinn, valgte menighetsrådene å kjøpe inn klassesett med nye Bibler til skolene. På den måten har alle en Bibel tilgjengelig på skolen, ingen har glemt igjen hjemme og de har samme utgave. Klassesettet inneholder 15 Bibler, og opplegget passer best for grupper som ikke er større enn det. Da får alle elevene hver sin Bibel å arbeide med.

I tillegg til klassesett med Bibler bruker jeg følgende utstyr: Tidslinjen (et pedagogisk verktøy - i form av et seks meter langt banner i PVS. Banneret illustrerer viktige bibelske hendelser gjennom hele GT og NT (Verbum 2016)). Bibler på hebraisk, gresk og norsk med gotisk skrift. Et mini-nytestamente $(4 \mathrm{~cm}$ x $2 \mathrm{~cm}$ ), og en liten leirkrukke med en «bokrull». Det å ha med fysiske artefakter, ikke bare bilder av ulike bibeltyper, er viktig. Elevene synes det er spennende å se på det jeg har med, og blir lett engasjert. Særlig mini-nytestamentet er populært. 


\section{FØRSTE DEL - PRESENTASJON PÅ POWERPOINT}

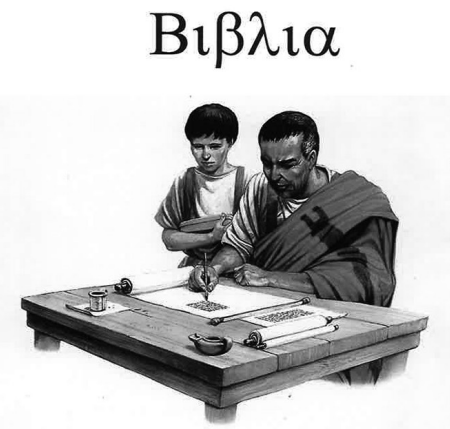

\section{Lysbilde $1^{1}$}

I første bolk bruker jeg lysbilder som hjelpemiddel. Det første bildet skaper erfaringsvis nysgjerrighet. Elevene gjetter at det står «Bibel» på bildet, ettersom de vet det er Bibelen de skal lære om. Jeg forklarer de greske bokstavene og forteller at ordet betyr bøker. Så spør jeg: «Hvilket ord kjenner dere som begynner på bibl...?». «Bibliotek», svarer de. Jeg forteller at ja, Bibelen er et helt lite bibliotek med til sammen 66 bøker.

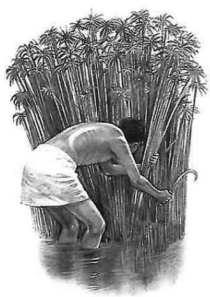

papyrusplante

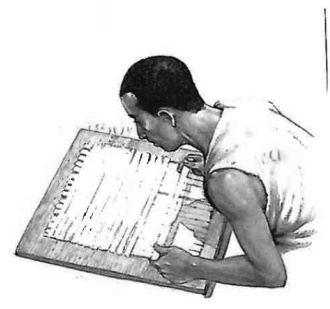

strimler fra planten ble ark

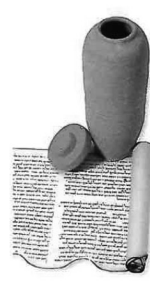

bokrull

\section{Lysbilde 2:}

1: Høsting av papyrusplante 2: Strimlene som legges sammen og deretter presses 3: Skriftrull og leirkrukke. Illustrasjon fra Graves 2003: 14-15

Jeg forteller videre elevene hvordan Bibelen først ble overlevert muntlig fra generasjon til generasjon. Vi trekker paralleller til våre dager om hvordan Asbjørnsen og Moe samlet inn folkeeventyrene.

$1 \quad$ Illustrasjonen er hentet fra Graves 2003. Fra omslaget av boka 
Ved hjelp av lysbilde 2 forklarer jeg hvordan stilkene på papyrusplanten, som kalles biblos ble skåret opp og limt sammen til ark for å skrive på. Arkene ble deretter rullet sammen og oppbevart i leirkrukker. Fram til ca. år 300 e. Kr. var papyrus det vanligste skrivematerialet. Da tok pergament, som er laget av fint dyreskinn (sau eller geit), gradvis over. (Sagrusten 2014:14.)

Jeg pleier å vise fram den lille leirkrukka jeg har med, og tar ut rullen som er inni. «Er den ekte?» spør ofte elevene. Så reflekterer vi over hvordan papiret og oppfinnelsen av boktrykkerkunsten gjorde det mulig å spre bøker på en helt annen måte enn tidligere da en måtte skrive for hånd.
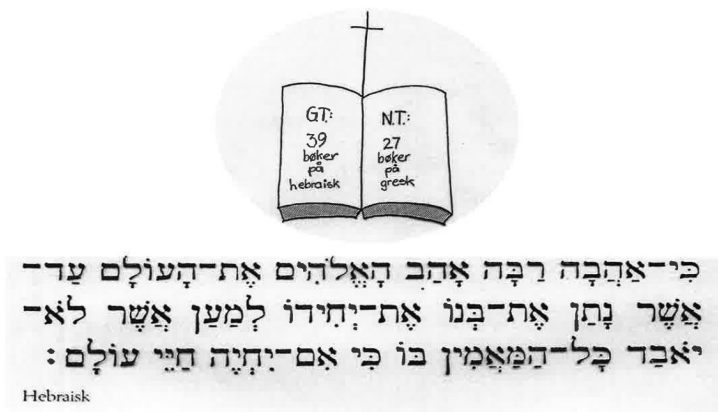

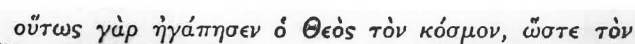

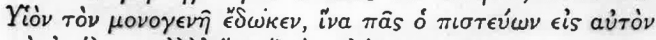

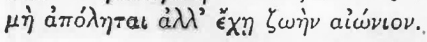
Gresk

\section{Lysbilde 3:}

Bibelsitatene er fra 1. Mos 1,1 (hebraisk) og Joh 3,16 (gresk) (Illustrasjon: ukjent opphav)

Bibelens to grunnspråk hebraisk og gresk presenteres. Vi samtaler om det finnes andre språk som bruker samme leseretning som hebraisk, fra høgre mot venstre. Elever med arabisk bakgrunn kan fortelle at de også leser slik. Elevene undres over forskjeller og likheter mellom hebraisk, gresk og norsk språk. Min erfaring, som kan gresk, er at det er nyttig kunnskap her. Barna synes det er spennende at jeg leser sitatene og oversetter ord for ord.

\section{Andre DeL}

Etter ca. 25-30 minutter med undervisning ved hjelp av lysbildene på powerpoint, tar jeg fram Tidslinjen (Verbum 2016). Jeg ruller ut banneret, og får hjelp av en 
lærer til å holde og rulle inn etter hvert som jeg kommenterer. På denne måten får elevene et raskt møte med viktige personer og hendelser i hele Bibelen.

Deretter sendes de ulike bibelutgavene (hebraisk, gresk, norsk med gotisk skrift og «mini-nytestamentet») rundt så alle få se på og bla i dem. Slik legges det til rette for at elevene undres over språkene som de ikke forstår, og vi reflekterer over verdien av å ha en Bibel på sitt eget morsmål. Elevene kommenterer ofte at bladene i Bibelen er så tynne, noe som kan tyde på at de ikke er vant med å bla i en vanlig Bibel og at dette er en førstegangsopplevelse.

Alle elevene får utdelt en Bibel fra klassesettet. Forskning på bibelbruk i trosopplæringen som Heid Leganger-Krogstad har gjort, viser at Bibelen som primær materiell artefakt i liten grad er i bruk. Hun mener barn i større grad bør møte Bibelen som ei bruksbok der de selv får slå opp og lese i den fysiske boka (Leganger-Krogstad 2019:146). Til denne delen av undervisningen får de arbeidsoppgaver.

\section{Arbeidsongave 1: \\ Kan du svarene?}

1. Hva betyr ordet Bibel?

2. Hvor mange bøker er det i Bibelen?

3. Hva står forkortelsen GT for ?

4. Hva står forkortelsen NT for?

5. Hvilket språk ble Det nye testamente først skrevet på?

6. Hvem er hovedpersonen i NT?

7. Hvem har skrevet flest brev i NT?

8. Hva handler Luk. 2. 1-14 om?

I denne oppgaven repeterer vi det jeg har undervist om i den første bolken. «Hvis dere har fulgt godt med», sier jeg, «kan dere svare på spørsmål 1-6 på egen hånd». Lysbilde nr. 3 er tilgjengelig på veggen slik at elevene kan lete etter svar der. Noen elever løser også spørsmål 7 og 8 på egen hånd, men det er de færreste. Det forteller meg at de ikke er vant med å slå opp i Bibelen, og ikke har gjort dette særlig mye før.

Spørsmål 7 finner de svaret på i innholdsoversikten, og spørsmål 8 går vi gjennom sammen:Jeg holder opp Bibelen og viser sidene med innholdsoversikten 
i begynnelsen av boka. Alle blar opp på samme sted i sin Bibel og følger med. «Bibelen har en spesiell form for koder for å finne fram», sier jeg. «Nå skal dere lære å knekke disse kodene. Luk 2,10 er en slik kode». Så forklarer jeg hva forkortelsen og tallene står for, og elevene slår opp. Vi finner riktig bok, kapittel, og vers, og de som vil, leser i kor sammen med meg. Til slutt ser vi på hele avsnittet fra vers 1-14, leser overskriften og finner ut hva dette handler om.

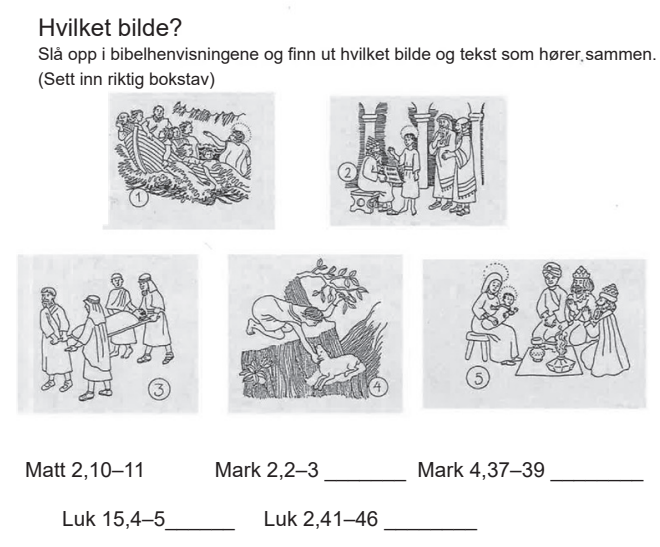

Arbeidsoppgave 2:

I arbeidsoppgave $2^{2}$ skal eleven sette sammen flere komponenter. Først må de finne riktig bok, kapittel og vers. Deretter skal de lese og oppfatte innholdet slik at de kan finne tekst og bilde som hører sammen. Slike sammensatte (multimodale) tekster utfordrer eleven til å orientere seg i mangfoldet av skrift og bilde, og løses ved å kombinere disse. Oppgaven gir god mestringsopplevelse. De aller fleste knekker raskt koden og fortsetter ivrig, noe som indikerer at motivasjonen er god. Hvis de ikke forstår, er de vanligvis utålmodige etter å få hjelp og komme videre.

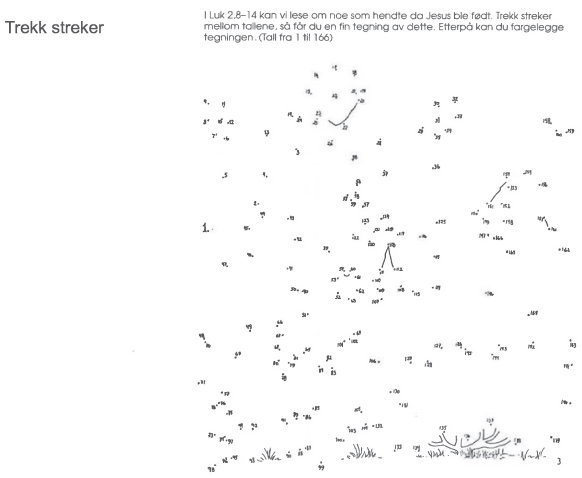

2 Oppgaven er hentet fra Birkedal/Jørgensen/Norderval (red.) 1990:15 


\section{Arbeidsoppgave $3^{3}$}

For å gi mulighet til mestring for alle, legger jeg vekt på å gi varierte oppgaver. Denne «prikk til prikk» -oppgaven kan alle løse på egen hånd, og lesekompetanse er ikke avgjørende.

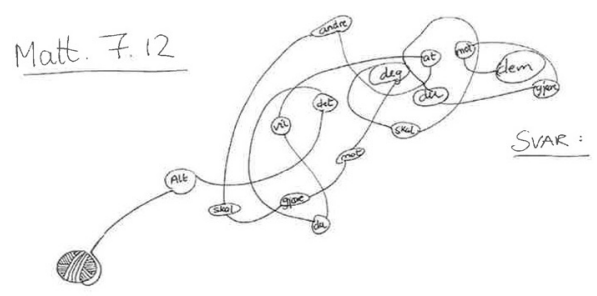

Arbeidsoppgave $4^{4}$ :

Dette er en leken oppgave som elevene ofte synes er morsom, der de skal nøste opp hvilket bibelord som skjuler seg i tråden. Når de har funnet svaret (- den gylne regel -), kan en samtale om at dette er et bud som finnes i flere religioner og hellige skrifter.

Det finnes en rekke bøker og hefter med bibeloppgaver som kan brukes på bibelkurs, i tillegg til de som er nevnt over. ${ }^{5}$

\section{ERFARINGER}

Jeg har ikke gjennomført noen form for systematisk evaluering av bibelkurset blant elevene. Likevel kan jeg ut ifra erfaring og pedagogisk skjønn tolke elevenes respons. Forskergruppen som står bak prosjektet «Bibelen i trosopplæringen barns og unges læring» (BIT), peker på at «engasjement kan leses gjennom særlig to parametere: stor grad av stille lytting og ivrig og aktiv deltakelse i aktiviteter» (Leganger-Krogstad 2019:65). Dette siste stemmer godt overens med mine erfaringer. Elevene viser utålmodighet etter å få gå videre og begynne på neste oppgave. Hvis de ikke forstår den, rekker de opp hånden og vil ha hjelp, før jeg ber dem gå videre. De glemmer tiden, og har ikke lyst å ta friminutt. På denne bakgrunn kan jeg se at bibelkurset har skapt konsentrasjon og kollektiv interesse hos elevene.

Jeg opplever mye god respons fra lærere, og tillater meg å ta med et sitat fra

3 Oppgaven er hentet fra Dahle 1992: 77

4 (c) Anny Holien

5 Eksempelvis er Det gamle testamente. Aktivitetsbibelen. (IKO-Forlaget 2002) og Det nye testamente. Aktivitetsbi-

belen. (IKO-Forlaget 2005) gode ressurser. Det finnes også mye på nettet. 
lærer «Hilde», som hun har godkjent at jeg bringer videre. Hun sa: «Det er meget lærerikt å ha [et] slikt opplegg fra en som brenner for faget ... Så det er et stort pluss for oss i Østre Toten at du reiser rundt og forteller om Bibelen». ${ }^{6}$

Et viktig moment når jeg holder kurs, handler om fritak og tilpasninger til elever med ulik religiøs tilhørighet. En av skolene har mange elever med muslimsk bakgrunn. De er ofte med i timene, men de har mulighet til å holde seg borte. For noen elever går grensen for deltakelse ved å lese fra Bibelen, eller det å selv holde i en Bibel. Jeg har opplevd lærere som har lest for elevene og vist dem tekster, fordi de selv ikke kunne holde i, og bla i Bibelen.

Dette må vi respekterte, men kanskje kan det være en mulighet for elevene med andre religioner til å fortelle litt som sin hellige bok, for eksempel koranen. Slik kan det skapes forståelse blant elevene om de ulike livssyn og religioner. Når det gjelder det å lese i kor, slik jeg ofte lar elevene gjøre i arbeidsoppgave 1, vurderer jeg dette fra gruppe til gruppe. I de mest sammensatte gruppene, eller de jeg ikke kjenner, spør jeg heller om noen vil lese høgt.

Min erfaring er at et godt skole-kirkesamarbeid bygger på gjensidig tillit og respekt mellom partene. Skolen har tillit til at bibelkurset er et undervisningsopplegg innenfor skolens rammer og retningslinjer. Jeg respekter dette og anerkjenner at elevene tror ulikt. Noen ganger sier en elev: «Jeg tror ikke på Gud, jeg». Slike utsagn tar jeg på alvor, og svarer ofte med at vi har trosfrihet i Norge, og det er veldig bra. Å laere om Bibelen og hva de kristne tror på, hører likevel med.

\section{Avslutining}

I denne artikkelen har jeg gjort rede for hvordan jeg underviser om Bibelen på 5. trinn, med et opplegg som er tilpasset ny læreplan i KRLE som trer i kraft høsten 2020. I vår digitaliserte verden er det viktig at barn får møte Bibelen som en fysisk bok som de kan bla i og bli kjent med. Som kirkelig ansatte kan vi komme skolen i møte og tilby vår kompetanse inn i KRLE-faget. Kanskje er innføringen av ny læreplan en anledning til å starte opp samarbeid, eller revidere og tenke nytt om det som er? Initiativet kan komme fra både skolen og kirken.

\section{LITTERATUR}

Birkedal, Erling/ Randi Jørgensen/ og Kristin Molland Norderval, (red). 1990.

Bruk Bibelen i skolen. Oppgaver 1. -6. klasse. IKO-Forlaget

Dahle, Tordis. 1992. På kryss og tvers i Bibelen. Bibeloppgaver for barn.

IKO-Forlaget

Graves, Sue. 2003. Hva er Bibelen? Norsk utgave 2007. IKO-Forlaget

$6 \ll$ Hilde» lærer på 5.trinn 
Leganger-Krogstad, Heid. 2019. Barn og unges respons på bibelundervisning i Den norske kirke. MF-rapport 1:2019

Sagrusten, Hans Johan. 2014. Det store puslespillet. Verbum

Utdanningsdirektoratet. 2017. Overordnet del-verdier og prinsipper for grunnopplaringen. https://udir.no/lareplanverket

Utdanningsdirektoratet. 2019. Lareplan i kristendom, religion, livssyn og etikk (KRLE) https://www.udir.no/1k20/rle01-03 